\title{
АРБИДОЛ КАК ОТПРАВНАЯ ТОЧКА В МИШЕНЬ- ОРИЕНТИРОВАННОМ КОНСТРУИРОВАНИИ АНТИВИРУСНЫХ АГЕНТОВ С ПРОТИВОВОСПАЛИТЕЛЬНЫМ КОМПОНЕНТОМ ДЕЙСТВИЯ
}

\section{M.Б. Навроцкий', К.В. Балакин ${ }^{2}$, R. Filosa ${ }^{3,4}$, С.Н. Лавренов ${ }^{5}$,}

А.С. Мкртчян', И.А. Новаков'

${ }^{1}$ ФГБОУ «Волгоградский государственный технический университет», 400005, Российская Федерация, г. Волгоград, пр. им. Ленина 28.

2 ЦВТ «ХимРар», 141401, Российская Федерация, Московская Область, городской округ Химки, г. Химки, ул. Рабочая, д. 2а, стр. 1.

${ }^{3}$ Department of Experimental Medicine, Section of Biotechnology, University of Campania 'Luigi Vanvitelli', 80138, Италия, Неаполь, S. Maria di Costantinopoli str. 16.

${ }^{4}$ Consorzio Sannio Tech, 82030, Италия, Аполлоза, Appia str.

5 Лаборатория химической трансформации антибиотиков, ФГБНУ «Научно-исследовательский институт по изысканию новых антибиотиков имени Г.Ф. Гаузе», 119021, Российская Федерация, г. Москва, ул. Большая Пироговская, 11.

DOI: 10.19163/MedChemRussia2021-2021-12

E-mail:maxim.nawrozkij@vstu.ru

Арбидол является оригинальным отечественным противовирусным препаратом, который, с момента своего появления и выхода на рынок, вызвал немало дискуссий в отношениибиомолекулярного механизма его действия. По химической структуре, Арбидол представляет собой функциональное производное 5-гидрокси-1Н-индол-3-карбоновой кислоты.

Исследования структурных аналогов Арбидола, выполненные в течение последних лет, позволили очертить спектр фармакологической активности этих соединений, включающий в себя иммунотропное действие, противовоспалительную активность и широкий спектр прямых противовирусных свойств. На текущий момент с уверенностью можно утверждать, что противовирусные и иммунотропные свойства Арбидола связаны как с его интерфероногенным действием, так и с его влиянием на специфические биомишени в жизненном цикле многих вирусов, например - вируса гриппа. Противовоспалительные свойства Арбидола и его структурных аналогов в значительной степени связаны с их способностью угнетать активность липооксигеназу типа 5.

Таким образом, молекула Арбидола представляет собой уникальный модельный объект для направленного конструирования высокоэффективных средств комбинированной терапии инфекционных заболеваний с фармакологически ценной комбинацией плейотропных эффектов, обусловленных multi-target'ным воздействием этих соединений. 